\title{
A Novel Repeated Sequence Located on the Bovine Y Chromosome: Its Application to Rapid and Precise Embryo Sexing by PCR
}

\author{
Soichi KAGEYAMA ${ }^{1)}$, Ikuya YOSHIDA ${ }^{2,3)}$, Kazuhiko KAWAKURA ${ }^{4)}$ and Koichi CHIKUNI ${ }^{5)}$ \\ () Hokkaido Animal Research Center, Shintoku 081-0038, ${ }^{2)}$ Center for Advanced Science and Technology and ${ }^{3)}$ Graduate School of \\ Environmental Earth Science, Hokkaido University, Sapporo 060-0810, ${ }^{4)}$ National Institute of Animal Industry, Tsukuba 305-0901 and \\ ${ }^{5)}$ National Institute of Livestock and Grassland Science, Tsukuba 305-0901, Japan
}

(Received 23 July 2003/Accepted 14 January 2004)

ABSTRACT. A novel repeated sequence specific to male cattle was identified and named S4. S4 is a highly repetitive sequence and is a $1.5 \mathrm{~kb}$ repeating unit that contains various internal repeated sequences. FISH analysis showed that S4 is localized on the whole long arm and the proximal region of the short arm of the Y chromosome. We found that a PCR primer set for S4 amplified a male-specific $178 \mathrm{bp}$ product in addition to a $145 \mathrm{bp}$ product common to both male and female cells. Although the origin of the $145 \mathrm{bp}$ product is unknown, it acts as a positive internal control in practical embryo sexing. Due to the high copy number of S4, PCR required only 0.5 pg purified DNA for accurate amplification. This made it possible to reduce the amount of biopsy sample required for embryo sexing and thus result in less damage to embryos manipulated. These studies indicate that embryo sexing based on the S4 sequence is ac curate and sensitive.

KEY WORDS: bovine Y chromosome, embryo sexing, FISH, PCR, repeated sequence.

Simple and precise methods for embryo sexing are important for the management and improvement of bovine strains. Polymerase chain reaction (PCR) is mainly used for sexing bovine embryos $[6,22]$ with various target sequences, including male-specific repetitive sequences $[3$, 20] and single copy genes on the $Y$ chromosome, such as amelogenine [4, 5] and ZFY genes [1, 9, 17]. When embryo sexing is performed with male-specific target sequences, one cannot distinguish the false-negative amplification caused by sampling errors from a lack of amplification in female samples. To solve this problem, various combinations of two different PCR primer sets, one for a male-specific sequence and another for a sequence common to both sexes, have been examined for PCR-based embryo sexing $[2,7,10,12,15,16,18,23,25]$. But this kind of PCR occasionally results in incorrect diagnoses due to the complexity of using two different primer sets in the PCR reaction. Here we report an improved embryo sexing method with conventional PCR. We found a novel repeated sequence, named $\mathrm{S} 4$, on the bovine Y chromosome. One of the PCR primer sets specific to the $\mathrm{S} 4$ sequence amplified a male-specific product in addition to a product common to both sexes. Furthermore, it was found that S4-based PCR is accurate and sensitive for practical embryo sexing.

\section{MATERIALS AND METHODS}

Isolation and analysis of a novel male-specific repetitive sequence: High molecular weight DNA was isolated from male or female bovine (Holstein) liver cells as previously described [19]. To isolate bovine repetitive sequences, 10 $\mu \mathrm{g}$ DNA from male or female liver cells was digested with EcoRI, separated by electrophoresis on a $1 \%$ agarose gel and stained with ethidium bromide. A visible DNA band of approximately $1.5 \mathrm{~kb}$ was extracted from the agarose gel, purified and cloned into the PUC118 plasmid vector (Takara, Japan). Plasmid DNA extracted from 50 recombinant clones was labeled with Digoxigenin (Boehringer, Germany) and used as DNA probes. For Southern blotting, 10 $\mu \mathrm{g}$ of DNA was digested with various restriction enzymes (BamHI, BglII, EcoRI, HindIII, MspI, PstI, RsaI, or TaqI), separated by electrophoresis, transferred to a nylon membrane (Hybond-N, Amersham, England) and hybridized as described previously [19]. For dot blot analysis, a dilution series of DNA (1 pg to $500 \mathrm{ng}$ ) was applied to the nylon membrane and hybridized with digoxigenin-labeled pS4 and $S R Y$ as a control single copy gene [24]. Nucleotide sequences of plasmids or PCR products were determined automatically with an Applied Biosystems 373S fluorescence sequencer according to the manufacturer's instructions.

PCR: One $n g$ of DNA was used for a PCR reaction with 15 pmol primers, Taq DNA polymerase (Boehringer, Germany) for 45 cycles $\left(95^{\circ} \mathrm{C}, 30 \mathrm{sec} ; 52^{\circ} \mathrm{C}, 45 \mathrm{sec} ; 72^{\circ} \mathrm{C}, 45\right.$ $\mathrm{sec})$. Primers used in the PCR study are shown in Table 1. After amplification, a $10 \mu \mathrm{l}$ aliquot was subjected to electrophoresis in a 3\% agarose gel and 1x TAE buffer $(40 \mathrm{mM}$ Tris-acetate, $\mathrm{pH} 8.0,1 \mathrm{mM}$ EDTA) and stained with $0.5 \mu \mathrm{g}$ / $\mathrm{m} l$ ethidium bromide. To examine the sensitivity of the PCR assay, various amounts of purified DNA (0.1 pg to 100 $p g$ ) were subjected to PCR. Each PCR was run in triplicate to control for PCR variation.

FISH: For fluorescence in situ hybridization (FISH), a 250 ng pS4 DNA was labeled with Biotin-16-dUTP (Boehringer, Germany) with a nick translation kit (Boehringer, Germany). The probe mixture consisted of $50 \%$ formamide, $10 \%$ dextran sulfate and $2 \mathrm{mg} / \mathrm{ml}$ BSA in $2 x \mathrm{SSC}$. For metaphase chromosome preparations, male peripheral blood 
Table 1. Oligonucleotide primers used in the present study

\begin{tabular}{llc}
\hline Name of the primer & Nucleotide sequence of primer set & Based spanned \\
\hline S4AF & CCATGGACTGTCGCCTATCAGGCTCCTC & $522-549$ \\
S4AR & CTCCACATCCTCTGCAGCACTTG & $770-792$ \\
& & \\
S4BF & CAAGTGCTGCAGAGGATGTGGAG & $770-792$ \\
S4BR & GAGTGAGATTTCTGGATCATATGGCTACT & $919-947$ \\
& & \\
S4CF & CCATGATAGTTCAGAGGTTAGGAC & $6-19$ \\
S4CR & GTCCATGGGGTCGCAAAGAGTCGG & $506-529$ \\
\hline
\end{tabular}

cells were cultured for $72 \mathrm{hr}$ in RPMI 1640 medium supplemented with $10 \%$ fetal bovine serum (Gibco BRL Life Technologies, U.S.A.) containing $2 \%$ phytohemagglutinin (Murex, England). Actively growing cells were harvested after a $1 \mathrm{hr}$ treatment with Colcemid (Gibco BRL Life Technologies, U.S.A.), incubated in $75 \mathrm{mM} \mathrm{KCl}$ for $15 \mathrm{~min}$, fixed with $3: 1(\mathrm{v} / \mathrm{v})$ methanol:acetic acid and dried on a slide. Hybridization and signal detection were performed as previously described [30].

Embryo sexing: For practical embryo sexing, 525 uterine-stage embryos were collected from superovulated donor cattle 7 days after estrus. Approximately $10 \%$ of the trophectoderm of the embryo was excised with a microblade (Micro Feather Blade, K-715, Feather Safety Razor Co., Japan) attached to the micromanipulator. The excised cell mass was transferred by a capillary glass pipette into a microfuge tube $(0.5 \mathrm{ml})$ containing $5 \mu l$ of distilled water, then denatured by heating in boiling water for $1 \mathrm{~min}$ to extract DNA followed by rapid chilling on ice. To assess the accuracy of PCR results, the remaining part of the dissected embryos were subjected to chromosomal analysis as described by Hishinuma et al. [8]. In this comparative experiment a total of 36 embryos were analyzed. For the sequence analysis, both the male-specific DNA band and the DNA band common to male and female embryos were excised from the gel.

Embryo transfer: To confirm the results of PCR, we also performed embryo transfer. Sexes of blastocyst embryos obtained from Holstein donors were determined by PCR, and 71 embryos judged to be female were transferred nonsurgically to synchronized heifers 6 to 8 days after estrus. Pregnancy diagnosis was performed with ultrasound between 39 and 50 days after estrus. The accuracy of the procedure was confirmed based on the sex of calves at birth.

\section{RESULTS}

To isolate a novel-repetitive sequence specific to male cattle, DNA derived from male liver cells was digested completely with EcoRI and subjected to electrophoresis. As shown in Fig. 1a, a single band (approximately $1.5 \mathrm{~kb}$ in size) was detected after ethidium bromide staining, suggesting that this band contained highly repeated sequences. Because a similar result was obtained with female DNA (Fig. 1a), the great majority of these repeated sequences

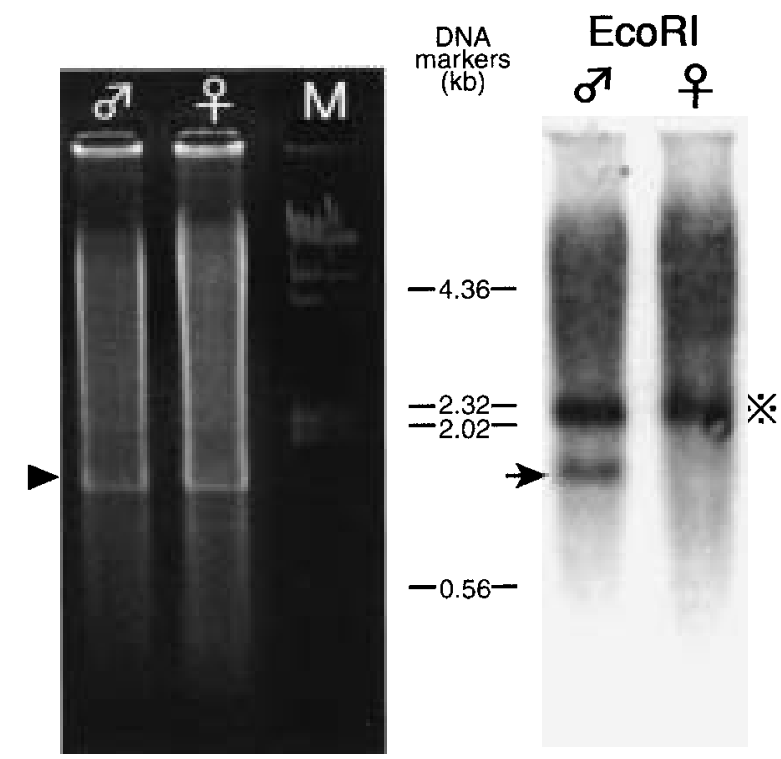

(a)

(b)

Fig. 1. Highly repeated sequences in the bovine genome. (a) Male and female genomic DNA was completely digested and subjected to electrophoresis on a $1 \%$ agarose gel and stained with Ethidium bromide. A $1.5 \mathrm{~kb}$ DNA band from male DNA was used for random cloning $(\boldsymbol{)})$, and a similar band was observed in female genomic DNA. (b) Southern blot analysis of EcoRI digested bovine DNA hybridized with clone pS4. A 1.5 $\mathrm{kb}$ male specific band $(\rightarrow$ ) was observed. A common band $(2.3$ kb) was observed in both samples $(※)$. M: $\lambda /$ HindIII digested molecular size markers.

seemed to be common to both sexes. The $1.5 \mathrm{~kb}$ band derived from the male liver cells was extracted from the agarose gel, purified and cloned into the pUC118 plasmid. Of 90 recombinants obtained, 50 clones were screened as hybridization probes for Southern blotting. In female and male DNA digested with EcoRI, one of these clones, pS4, detected a male-specific $1.5 \mathrm{~kb}$ band in addition to a $2.3 \mathrm{~kb}$ band common to both male and female cells (Fig. 1b). Various sex-dependent polymorphisms were also observed in DNA digested with BamHI, BglII, HindIII, MspI, PstI, RsaI, or TaqI (data not shown). The copy number of S4, the insert of plasmid $\mathrm{pS} 4$, was estimated by dot blot assay. The signal intensity of S4 in the male liver cells was about 100 times 
that of a control signal copy gene, $S R Y$, and 2-3 times that of S4 in the female liver cells (data not shown), suggesting that $\mathrm{S} 4$ was a highly repetitive sequence in the male bovine genome. Consistent with these results, FISH analysis

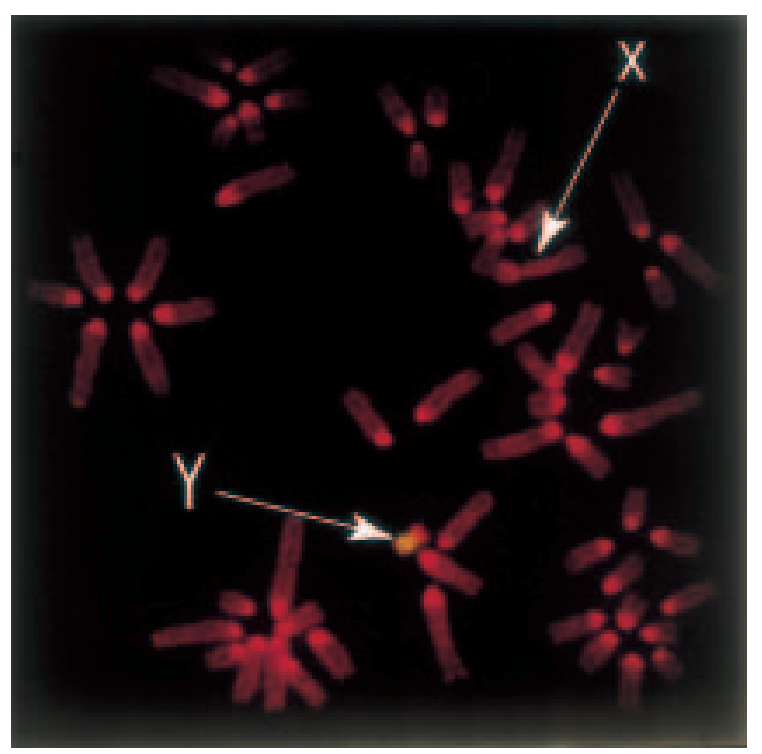

Fig. 2. Chromosomal localization of the S4-repeated sequence revealed by FISH. Strong signals were detected throughout the long arm, and weak signals in the proximal region of the short arm of the $\mathrm{Y}$ chromosome were also observed. X: X chromosome, Y: Y chromosome. showed that S4 was localized throughout the long arm of the Y chromosome (Fig. 2). We also observed weak signals on the proximal region of the short arm of the $\mathrm{Y}$ chromosome. No consistent signals were observed on autosomes or the $\mathrm{X}$ chromosome, although very faint signals were occasionally found in the telomere region of autosomes.

As shown in Fig. 3, S4 was 1542 bp long and contained various internally repeated sequences. Long internally repeated sequences found in S4 were 120 bp in length (designated as R1 and R2). The R1 and R2 nucleotide sequences were $80.5 \%$ identical. We also identified short 27 bp tandem repeated sequences (R3 and $\mathrm{R} 4$ ), and these were $81.4 \%$ identical. Four-nucleotide units (5'-GAAA-3') distributed throughout the $\mathrm{S} 4$ sequence and a $(\mathrm{GpT})_{26}$ repeat sequence were found in the S4 sequence (Fig. 3). Based on a homology search analysis, it was found that the bovine short interspersed repetitive sequences (SINE), BovA (115 bp) and Bov-tA (188 bp) were closely related to the $120 \mathrm{bp}$-internal repeats R1 (80\% identity) and R2 (87\% identity). A part of S4 (the region between bases 1 and 453) showed close similarity to a Bos taurus microsatellite sequence, INRA149 (bases 27 and 427) (83.4\% identity; Fig. 3). Other than these sequences, we did not find significant similarity with the DNA sequences deposited in the EMBL database, including the $B$. tauras repeating sequence family BRY, which occurs throughout the Y chromosome [13,14,21,27], or the bovine repeated sequence FBNY [29], which is located on the $\mathrm{Y}$ chromosome $\left(\mathrm{Y}_{\mathrm{q}} 12-\mathrm{Y}_{\mathrm{q}}\right.$ ter $)$ [29]. Analysis of the protein-coding capacity revealed that there are no extensive open reading frames in the $\mathrm{S} 4$ sequence.

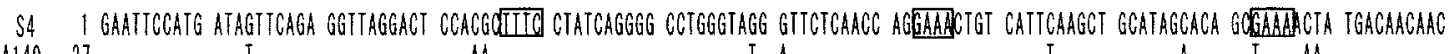

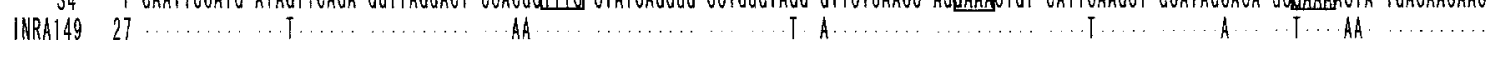

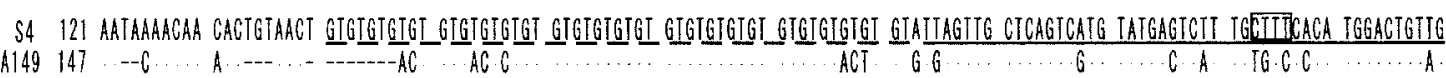

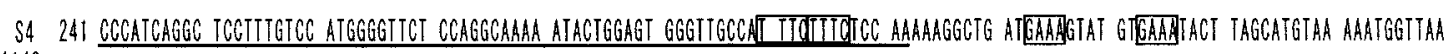

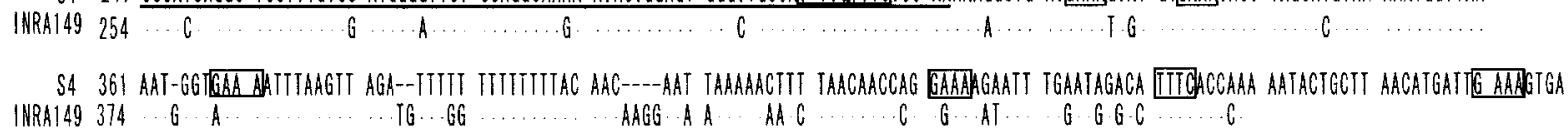

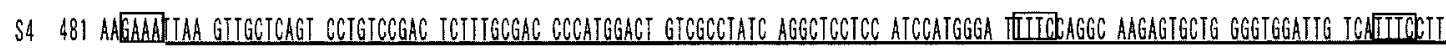

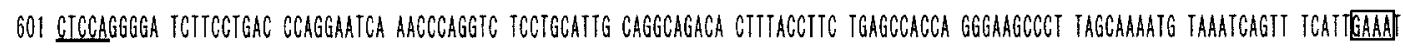

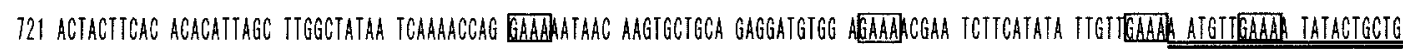

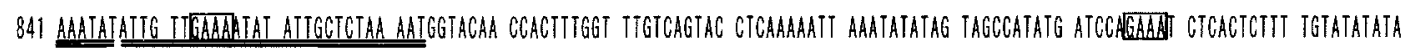

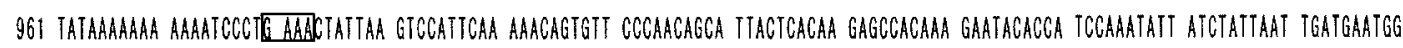

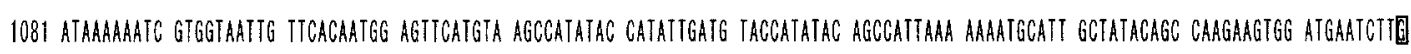

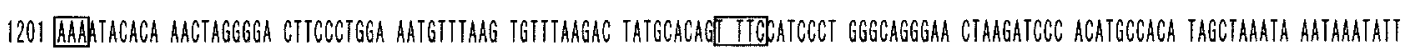

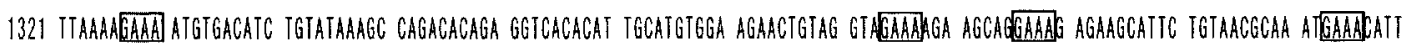

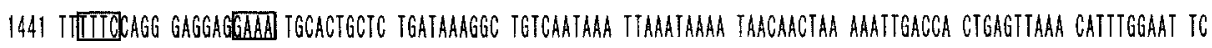

Fig. 3. Nucleotide sequence of S4. S4 was 1542 bp long and contained various internal repeats: R1 and R2 [underscored with a single lire (-)]; R3 and R4 (=); (GT)n (-----); (5'-GAAA-3') repeat units are boxed. Sequence comparisons were performed between S4 and the consensus sequence INRA149 by means of the homology search program BLAST in the EMBL DNA database. Sequence information was deposited into the DDBJ sequence database. The accession number is D16357. 


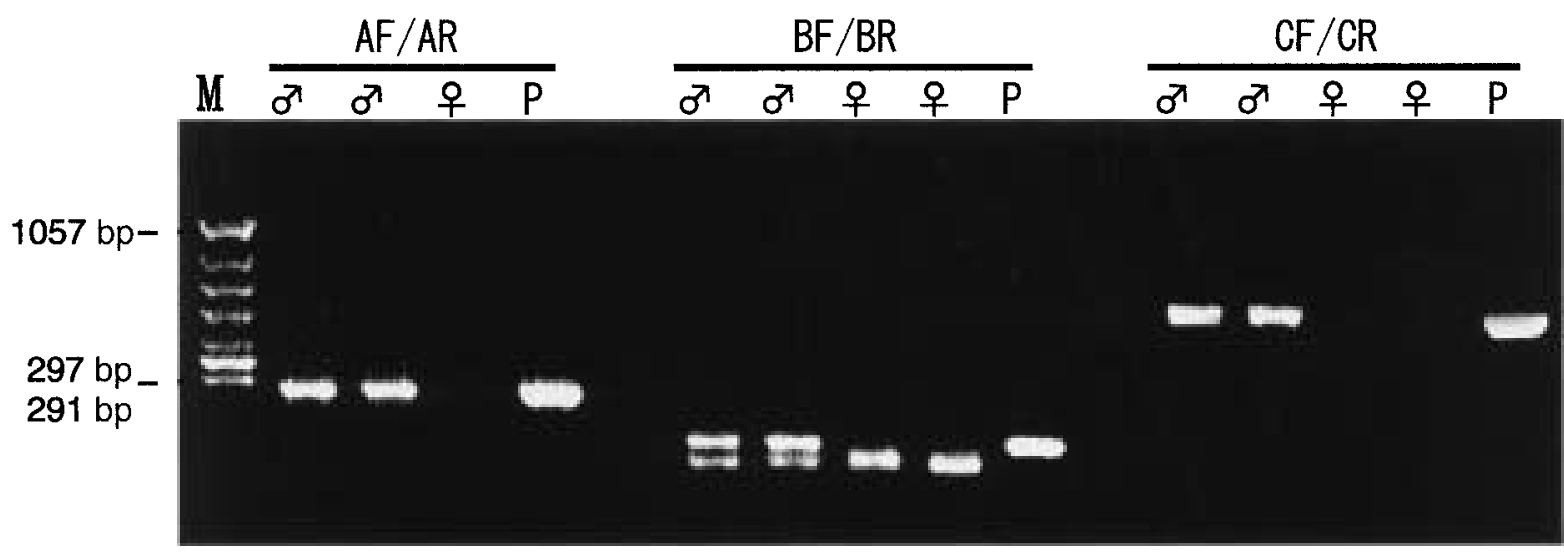

Fig. 4. PCR with three different primer sets specific to S4. M: size marker, $\sigma^{7}:$ bovine male genomic DNA ( $50 \mathrm{ng}$ ); 早: bovine female genomic DNA (50 ng); P: plasmid DNA (p-S4) (250 pg).

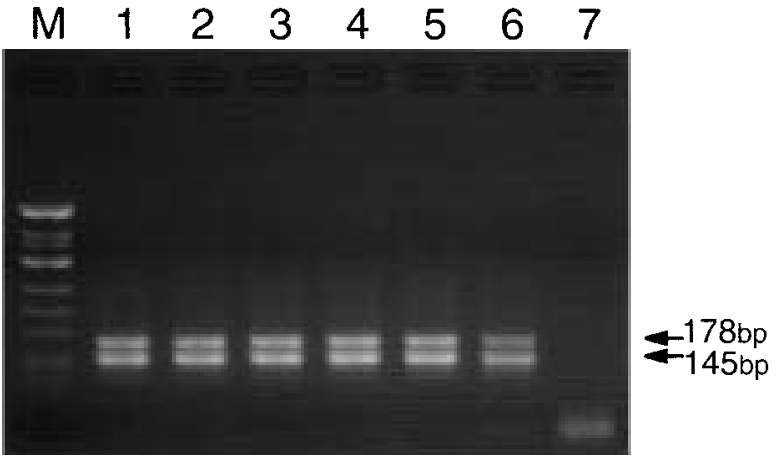

Fig. 5. Sensitivity of PCR with S4BF/BR primers. M: DNA size marker $(\varphi X 174 / H i n f$ I digest); Lane 1: $50 \mathrm{pg}$, Lane 2: $12.5 \mathrm{pg}$, Lane 3: 6 pg, Lane 4: 3 gg, Lane 5: 1 pg, Lane 6: 0.5 pg, Lane 7: (-) control.

We designed three different PCR primer sets specific to the S4 sequence (Table 1). One of these primer sets, S4AF and S4AR, gave rise to a male-specific PCR product with the male DNA (Fig. 4). This PCR product migrated on the agarose gel at its expected molecular weight $(271 \mathrm{bp})$. Amplification was not detected with the female genomic DNA. Similarly, S4CF and S4CR gave a PCR product (524 bp) only in the male DNA. To our surprise, a third primer set, S4BF and S4BR, consistently amplified an unexpected PCR product ( $145 \mathrm{bp}$ ) in addition to a product $(178 \mathrm{bp})$ predicted from the $\mathrm{S} 4$ sequence. The former product was also detected in the female DNA, and therefore assumed to be common to both male and female cells. The amplification efficiency of the $145 \mathrm{bp}$ product was almost identical to that of the male-specific $178 \mathrm{bp}$ product. This suggests that the $145 \mathrm{bp}$ product can be used as an internal positive control in embryo sexing.

To estimate the minimum amount of DNA necessary for proper amplification in the PCR reaction, a dilution series of purified male DNA was used for PCR with the S4BF/BR

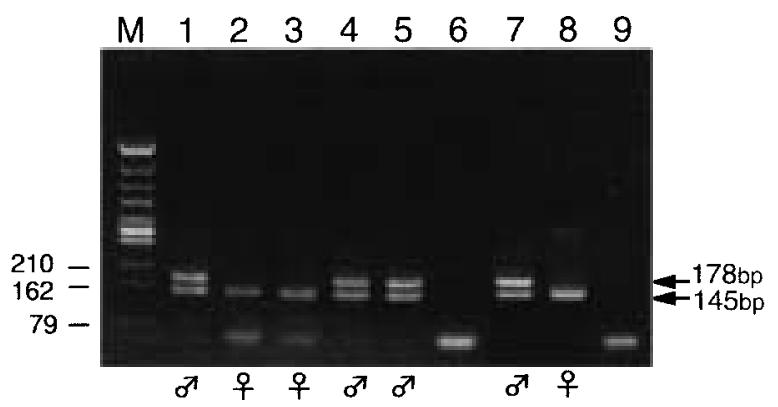

Fig. 6. Embryo sexing by the S4-based PCR method. M: DNA size marker ( $\varphi$ X174/Hinf I digest); Lanes 1, 4 and 5, male embryo biopsies. Lanes 2 and 3, female embryo biopsies; Lanes 6 and 9, negative control; Lanes 7 and 8, male and female genomic DNA (200 pg).

primer set (Fig. 5). After 45 cycles of amplification, PCR products were detected in reactions containing as little as 0.5 $p \mathrm{~g}$ of DNA, much less than the amount of DNA in a single mammalian cell. PCR products could not be reproducibly amplified with $0.1 \mathrm{pg}$ of DNA (data not shown).

To test the accuracy of our sexing method, the sex of embryos was determined by conventional karyotyping, followed by our PCR-based sexing. Biopsy samples were collected from 36 embryos and subjected to PCR. Chromosome analysis was then performed with the remaining embryos. The sexes predicted by the PCR method agreed with those determined by conventional karyotyping (26 male, 10 female).

Next we applied the S4-based PCR to practical embryo sexing (Fig. 6). Of 525 uterine-stage embryos tested, 481 $(91.6 \%)$ gave rise to male- or female-specific PCR products with the $\mathrm{S} 4 \mathrm{BF} / \mathrm{BR}$ primers (Table 2). The sex ratio predicted by the PCR method was almost 50:50. A PCR product was not detected in the remaining 44 embryos $(8.4 \%)$. Embryos judged to be female by the PCR method were 
Table 2. Embryo-sexing by PCR with S4BF/BR primer set

\begin{tabular}{cccc}
\hline \multirow{2}{*}{$\begin{array}{c}\text { No. of } \\
\text { embryos tested }\end{array}$} & \multicolumn{3}{c}{ No. (\%) of successfully sexed } \\
\cline { 2 - 4 } & Male & Female & Total \\
\hline 525 & $253(52.6)$ & $228(47.4)$ & $481(91.6)$ \\
\hline
\end{tabular}

Table 3. Embryo transfer of sexed embryos

\begin{tabular}{|c|c|c|c|c|c|}
\hline \multicolumn{3}{|c|}{ No. $(\%)$ of } & \multirow{2}{*}{$\begin{array}{c}\text { Sex predicted } \\
\text { by PCR } \\
(\mathrm{M} / \mathrm{F})\end{array}$} & \multirow{2}{*}{$\begin{array}{l}\text { Phenotypic } \\
\text { sex after } \\
\text { calving }(\mathrm{M} / \mathrm{F})\end{array}$} & \multirow[b]{2}{*}{ Accuracy } \\
\hline $\begin{array}{l}\text { embryos } \\
\text { transferred }\end{array}$ & Pregnancies & Births & & & \\
\hline 71 & $40(56.3 \%)$ & 25 & $0 / 25$ & $1 / 24$ & $96.0 \%$ \\
\hline
\end{tabular}

M: Male, F: Female.

transferred into synchronized heifers. Out of 71 transfers, 40 were diagnosed as pregnant by rectal palpation, and, from those, 25 calves were born and grew normally (Table 3). All but one of these calves was female.

\section{DISCUSSION}

We isolated a male-specific repeated sequence $\mathrm{S} 4$. Although S4 contained various internal repeating units and some of them were similar to short repeating sequences such as bovine SINEs $[11,28]$, database analysis showed that S4 is a novel repeated sequence. FISH analysis showed that S4 is localized along the entire length of the long arm as well as the proximal region of the short arm of the $\mathrm{Y}$ chromosome. The PCR primers specific for $\mathrm{S} 4, \mathrm{~S} 4 \mathrm{BF} / \mathrm{BR}$, gave rise to a male specific $178 \mathrm{bp}$ product along with a $145 \mathrm{bp}$ product common to both males and females. Consistent with the fact that $\mathrm{S} 4$ was highly repetitive in the male bovine genome, we detected these two PCR products with as little as $0.5 \mathrm{pg}$ template DNA. Weikard et al. [29] reported that one primer pair set simultaneously amplifies male-specific FBNY and microsatellite FBN17 sequences. A PCR product derived from FBN17 that was present in both sexes served as a positive internal control. But in contrast to our findings, their PCR method required at least $10 \mathrm{pg}$ DNA for successful embryo sexing. Thus, the sensitivity of the S4based sexing method is about 20 times higher than that of their PCR method. It will reduce the amount of biopsy sample needed and will result in less damage to the transferred embryos.

We applied this PCR method to the bovine embryo sexing and found that the sexes predicted by the PCR method agreed with the actual sexes of newborn individuals in 24 out of 25 cases, so that the accuracy of the S4-based embryo sexing method is $96 \%$. The commercial PCR-sexing protocols for bovine embryos utilize Y-specific primers in conjunction with bovine control primers, and provide 90-95\% efficiency and 93-98\% accuracy $[18,20,26]$. Therefore, the PCR sexing procedure developed here appears to be sufficiently accurate for bovine embryo sexing. In one excep- tional case, the predicted sex was female but the actual sex was male. This may have been due to an error in embryo handling or during the biopsy. Further, the high conception rate of biopsied embryos indicated that biopsy had little or no effect on pregnancy rates when fresh embryos were used.

The origin of the $145 \mathrm{bp}$ PCR product is unknown. The S4 sequence itself does not contain the $145 \mathrm{bp}$ sequence, because the $145 \mathrm{bp}$ product was not amplified in the control PCR mixture which contained the pS4 plasmid as a DNA template (see Fig. 4, lane 9). We failed to determine the DNA sequence of the 145 bp product, probably due to heterogeneity of the PCR product extracted from the agarose gel (data not shown). Therefore it is likely that multiple target sequences of S4BF/BR (145 bp long) are dispersed throughout the bovine genome. This may explain why consistent signals were not identified on the $\mathrm{X}$ chromosome or on autosomes in FISH analysis with the pS4 probe, even though the same DNA probe gives rise to the $2.3 \mathrm{~kb}$ band in Southern blots indicating that it is common to both male and female samples. Further analysis is necessary to identify the origin of the $2.3 \mathrm{~kb}$ band found in the Southern blots.

In conclusion, with the novel repeated $\mathrm{S} 4$ sequence, we improved the conventional PCR-based bovine embryo sexing method. With a single primer set, two PCR products, a male-specific PCR product and a PCR product present in both sexes, can be detected simultaneously. Furthermore, a high copy number of the target S4 sequences ensures sensitive and accurate embryo sexing.

ACKNOWLEDGEMENTS. The authors thank Dr. H. Yamashina, Hokkaido agricultural Development Corporation, Taiki-cho, Japan for help with embryo transfer. This study was supported in part by Grants-in-Aid for Scientific Research from Ministry of Education, Science, Sports and Culture, Japan.

\section{REFERENCES}

1. Aasen, E. and Medrano, J.F. 1990. Amplification of the ZFY and ZFX genes for sex identification in humans, cattle, sheep 
and goats. Biotechnology 8: 1279-1281.

2. Alves, B.C., Hossepian, de Lima, V.F., Teixeira, C.M. and Moreira, Filho, C.A. 2003. Use of primers derived from a new sequence of the bovine $\mathrm{Y}$ chromosome for sexing Bos taurus and Bos indicus embryos. Theriogenology 59: 1415-1419.

3. Bredbacka, P. and Peippo, J. 1995. Pcr-sexing of bovine embryos: a simplified protocol. Theriogenology 44: 167-176.

4. Chen, C.M., Hu, C.L., Wang, C.H., Hung, C.M., Wu, H.K., Choo, K.B. and Cheng, W.T. 1999. Gender determination in single bovine blastomeres by polymerase chain reaction amplification of sex-specific polymorphic fragments in the amelogenin gene. Mol. Reprod. Dev. 54: 209-214.

5. Ennis, S. and Gallagher, T. F. 1994. A pcr-based sex-determination assay in cattle based on the bovine amelogenin locus. Anim. Genet. 25: 425-427.

6. Faber, D.C., Molina, J.A., Ohlrichs, C.L., Vander, Zwaag, D.F. and Ferre, L.B. 2003. Commercialization of animal biotechnology. Theriogenology 59: 125-138.

7. Herr, C.M., Holt, N.A., Matthaei, K.I. and Reed, K.C. 1990. Sex of progeny from bovine embryos sexed with a rapid Ychromosome-detection assay. Theriogenology 33: 247.

8. Hishinuma, M., Kanagawa, H., Utaka, K., Sakai, M., Teranishi, M. and Seike, N. 1984. Chromosomal sex determination of bovine embryos. J. Mamm. Ova. Res. 1: 169-176.

9. Kirkpatrick, B.W. and Monson, R.L. 1993. Sensitive sex determination assay applicable to bovine embryos derived from IVM and IVF. J. Reprod. Fertil. 98: 335-340.

10. Kudo, T., Sato, S. and Sutou, S. 1993. Sexing of bovine embryos with male-specific repetitive DNA by polymerase chain reaction: cloning and characterization of bovine malespecific repetitive DNA. J. Reprod. Dev. 39: 55-63.

11. Lenstra, J.A., van Boxtel, J.A., Zwaagstra, K.A. and Schwerin, M. 1993. Short interspersed nuclear element (SINE) sequences of the Bovidae. Anim. Genet. 24: 33-39.

12. Machaty, Z., Paldi, A., Csaki, T., Varga, Z., Kiss, I., Barandi, Z. and Vajta, G. 1993. Biopsy and sex determination by PCR of IVF bovine embryos. J. Reprod. Fertil. 98: 467-470.

13. Matthews, M.E. and Reed, K.C. 1991. A DNA sequence that is present in both sexes of Artiodactyla is repeated on the Y chromosome of cattle, sheep, and goats. Cytogenet. Cell Genet. 56: $40-44$.

14. Matthews, M.E. and Reed, K.C. 1992. Sequences from a family of bovine Y-chromosomal repeats. Genomics 13: 12671273.

15. Park, J.H., Lee, J.H., Choi, K.M., Joung, S.Y., Kim, J.Y., Chung, G.M., Jin, D.I. and Im, K.S. 2001. Rapid sexing of preimplantation bovine embryo using consecutive and multiplex polymerase chain reaction (PCR) with biopsied single blastomere. Theriogenology 55: 1843-1853.

16. Peura, T., Hyttinen, J.M., Turunen, M. and Janne, J. 1991. A reliable sex determination assay for bovine preimplantation embryos using the polymerase chain reaction. Theriogenology 35: 547-555.

17. Pollevick, G.D., Giambiagi, S., Mancardi, S., de Luca, L., Burrone, O., Frasch, A.C. and Ugalde, R.A. 1992. Sex determination of bovine embryos by restriction fragment polymorphisms of PCR amplified ZFX/ZFY loci. Biotechnology 10: 805-807.

18. Roschlau, K., Roschlau, D., Roselius, R., Dexne, U., Michaelis, U., Strehl, R., Unicki, P. and Rink, N. 1997. Over 5 years experience in sexing of bovine morulae and blastocysts during routine embryo transfer. Theriogenology 47: 273.

19. Sambrook, J., Fritsch, E.F. and Maniatis, T. 1989. Molecular Cloning: A Laboratory Manual 2nd ed., Cold Spring Harbor Laboratory. Cold Spring Harbor, NY.

20. Schroder, A., Miller, J.R., Thomsen, P.D. and Avery, B. 1990 Sex determination of bovine embryos using the polymerase chain reaction. Anim. Biotechnol. 1: 121-133.

21. Schwerin, M., Gallagher, D.S. Jr., Miller, J.R. and Thomsen, P.D. 1992. Mapping of repetitive bovine DNA sequences on cattle Y chromosomes. Cytogenet. Cell Genet. 61: 189-194.

22. Seidel, G.E. Jr. 1999. Sexing mammalian spermatozoa and embryos--state of the art. J. Reprod. Fertil. (Suppl.) 54: 477487.

23. Shea, B.F. 1999. Determining the sex of bovine embryos using polymerase chain reaction results: a six-year retrospective study. Theriogenology 51: 841-854.

24. Sinclair, A.H., Berta, P., Palmer, M.S., Hawkins, J.R., Griffiths, B.L., Smith, M.J., Foster, J.W., Frischauf, A.M., Lovell, Badge, R. and Goodfellow, P.N. 1990. A gene from the human sex-determining region encodes a protein with homology to a conserved DNA-binding motif. Nature 346: 240-244.

25. Taneja, M., Rao, K.B., Gangawane, S., Zawar, S.G. and Totey, S.M. 1998. Rapid sexing of bovine preimplantation embryos using polymerase chain reaction: production of calves with predetermined sex under field conditions. Indian J. Exp. Biol. 36: $1201-1208$.

26. Thibiera, M. and Nibarta, M. 1995. The sexing of bovine embryos in the field. Theriogenology 43: 71-80.

27. Thomsen, P.D. and Jorgensen, C.B. 1994. Distribution of two conserved, male-enriched repeat families on the Bos taurus Y chromosome. Mamm. Genome 5: 171-173.

28. Vaiman, D. 1999. The molecular genetics of cattle. pp. 123161. CAB International The Genetics of Cattle.

29. Weikard, R., Kuhn, C., Brunner, R.M., Roschlau, D., Pitra, C., Laurent, P. and Schwerin, M. 2001. Sex determination in cattle based on simultaneous amplification of a new male-specific DNA sequence and an autosomal locus using the same primers. Mol. Reprod. Dev. 60: 13-19.

30. Yoshida, I., Kimura, H. and Takagi, N. 1996. The mouse Mcmd gene for DNA replication protein P1MCM3 maps to bands A3-A5 on chromosome 1 by fluorescence in situ hybridization. Genomics 32: 483-484. 